Article

\title{
The Synergistic Effect of Iodide and Sodium Nitrite on the Corrosion Inhibition of Mild Steel in Bicarbonate-Chloride Solution
}

\author{
Gaius Debi Eyu *, Geoffrey Will, Willem Dekkers and Jennifer MacLeod \\ Department of Chemistry, Physics and Mechanical Engineering, Queensland University of Technology, \\ Brisbane QLD 4000, Australia; g.will@qut.edu.au (G.W.); w.dekkers@qut.edu.au (W.D.); \\ jennifer.macleod@qut.edu.au (J.M.) \\ * Correspondence: gaius.eyu@qut.edu.au; Tel.: +61-24-224-9877 \\ Academic Editor: Richard Thackray \\ Received: 26 September 2016; Accepted: 21 October 2016; Published: 26 October 2016
}

\begin{abstract}
The effect of potassium iodide (KI) and sodium nitrite $\left(\mathrm{NaNO}_{2}\right.$ inhibitor on the corrosion inhibition of mild steel in chloride bicarbonate solution has been studied using electrochemical techniques. Potentiodynamic polarisation data suggest that, when used in combination, KI and $\mathrm{NaNO}_{2}$ function together to inhibit reactions at both the anode and the cathode, but predominantly anodic. $\mathrm{KI} / \mathrm{NO}_{2}{ }^{-}$concentration ratios varied from 2:1 to 2:5; inhibition efficiency was optimized for a ratio of 1:1. The surface morphology and corrosion products were analysed using scanning electron microscopy (SEM) and X-ray diffractometry (XRD). The latter shows that the addition of $\mathrm{I}^{-}$to $\mathrm{NO}_{2}$ facilitates the formation of a passivating oxide $\left(\gamma-\mathrm{Fe}_{2} \mathrm{O}_{3}\right)$ as compared to $\mathrm{NO}_{2}{ }^{-}$alone, decreasing the rate of metal dissolution observed in electrochemical testing. The synergistic effect of $\mathrm{KI} / \mathrm{NO}_{2}{ }^{-}$inhibition was enhanced under the dynamic conditions associated with testing in a rotating disc electrode.
\end{abstract}

Keywords: mild steel; bicarbonate solution; polarization; EIS; iodide ion; passivation

\section{Introduction}

Bicarbonate-induced corrosion is potentially relevant in many applications, such as wellbore systems for geological sequestration of $\mathrm{CO}_{2}$ [1], and coal seam gas infrastructure. Studies indicate that chloride [2] and $\mathrm{HCO}_{3}{ }^{-}$concentrations are correlated with carbon steel dissolution [3-5], with consequences for service life. Many methods such as cathodic protection, phosphating, coating and the use of inhibitors [6-9] have been adopted to reduce corrosion. Among them, the use of an inhibitor is one of the most popular, economic, convenient and practical measures for corrosion control in certain situations [10]. Inorganic inhibitors such as nitrite, phosphate and chromate have been used in acidic solutions and industrial water. However, the use of chromates has been restricted in recent years because of their toxic nature. Sodium nitrite has been used as corrosion inhibitor in gasoline and petroleum product pipelines [11], but it can be toxic in large amounts [12]. Nitrites retard anodic reactions by oxidizing ferrous ions to ferric ions at the steel surfaces to produce a stable tenacious film of iron (III) oxide [13] as:

$$
\begin{gathered}
\mathrm{Fe} \rightarrow \mathrm{Fe}^{2+}+2 \mathrm{e}^{-} \\
\mathrm{Fe}^{2+}+2 \mathrm{OH}^{-}+2 \mathrm{NO}_{2}{ }^{-} \rightarrow 2 \mathrm{NO}+\gamma-\mathrm{Fe}_{2} \mathrm{O}_{3}
\end{gathered}
$$

The resulting complex $\left(2 \mathrm{NO}+\gamma-\mathrm{Fe}_{2} \mathrm{O}_{3}\right)$ can either inhibit or catalyse corrosion, depending on its relative stability. Nitrite raises the critical breakdown potential and the potential at the steel surface, and when the concentration is sufficient, the steel is moved into the passive region corresponding to the $\mathrm{Fe}_{2} \mathrm{O}_{3}$ region in the Pourbaix diagram. Conversely, the corrosion rate can be increased when 
the nitrite concentration is below a critical level [14]. Raman and Siew also reported that $\mathrm{NO}_{2}{ }^{-}$has a concentration-dependent effect on the susceptibility of stainless steel to stress corrosion cracking (SCC) when chloride is present. They find that SCC was significantly decreased at low nitrite concentrations (1400 and 2800 ppm), but that it increases considerably at nitrite concentration of $5600 \mathrm{ppm}$ [15].

In recent years, the performance of inhibitors has been enhanced by the addition of either organic or inorganic compounds [16]. For example, Oguzie et al. [17] studied the synergistic corrosion inhibition of methionine and potassium iodide in acidic media. They concluded that potassium iodide enhanced methionine inhibition significantly when present in a 5:5 ratio. Pavithra et al. [18] also reported that the addition of potassium iodide to benzisothiozole-3-piperizine hydrochloride improved the corrosion resistance of mild steel in acid conditions. To date, the research focus has been on the synergistic effect of potassium iodide and organic inhibitors. There are no studies of the influence of KI on inorganic inhibitors on the corrosion of steel in both acidic and alkaline media under stagnant and dynamic conditions. The present study investigates the effect of potassium iodide and its synergistic effect on sodium nitrite inhibition on the corrosion of mild steel in high bicarbonate-chloride solution under stagnant and dynamic conditions. It is anticipated that the outcome of this study will enhance the applications of sodium nitrite.

\section{Results and Discussion}

\subsection{Effect of Sodium Nitrite Concentration}

Figure 1 shows the polarisation curve for mild steel in bicarbonate/chloride solution containing different nitrite concentrations. The anodic regime was apparently active in solutions without nitrite, while passive behaviour occurred in solutions containing nitrite. Passivation is eliminated in the absence of sodium nitrite due to chloride ions at the metal surface, which is responsible for the anodic sensitivity $[19,20]$ and thus, an increase in anodic current density.

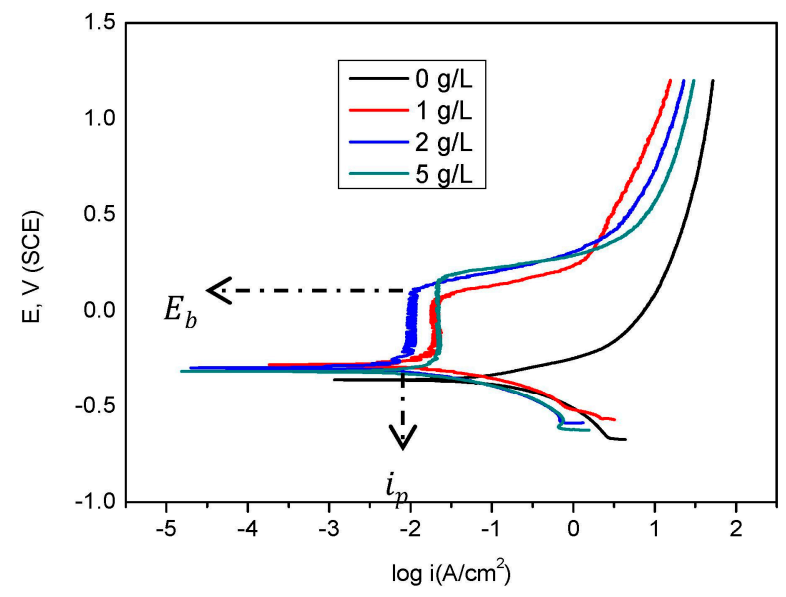

Figure 1. Polarization curves for mild steel in bicarbonate/chloride solution in absence and presence of different concentration of sodium nitrite at $2000 \mathrm{rpm}$ at room temperature.

The breakdown potential increases with nitrite concentrations. The anodic current densities decreased with an increase in nitrite concentration, resulting in a decrease in corrosion current densities. The results are consistent with the formation of a passive film, which slows down the corrosion rate $[14,21]$. We found that, over most of the tested range, the passive current density $\left(i_{p}\right)$ decreases with increasing nitrite concentrations. However, the achieved inhibition efficiency reached an optimum value at $2 \mathrm{~g} / \mathrm{L}$, and a further nitrite increase in nitrite concentration to $5 \mathrm{~g} / \mathrm{L}$ resulted in a decrease in efficiency. Together, these results suggest that, when nitrite concentration is below the critical level, the steel surface is partially passivated and when the concentration is above the optimum level, 
the ionic conductivity of the solution is raised, increasing the corrosion rate [21]. Generally, nitrite repairs the oxide layer on the steel/solution interface. The inhibition mechanism is based on the oxidation of iron (II) to iron (III) oxide. Oxide film nucleation is initiated when the Fe (II) cations combine with $\mathrm{H}_{2} \mathrm{O}$ molecules. The process involves reduction and oxidation of nitrite and $\mathrm{Fe}^{2+}$, respectively, as:

$$
\begin{gathered}
2 \mathrm{NO}_{2}{ }^{-}+4 \mathrm{e}^{-} \rightarrow \mathrm{N}_{2} \mathrm{O}+3 \mathrm{O}^{2-} \text { (reduction) } \\
\mathrm{Fe} \rightarrow \mathrm{Fe}^{2+}+2 \mathrm{e}^{-} \text {(oxidation) } \\
\mathrm{Fe}^{2+}+2 \mathrm{OH}^{-}+2 \mathrm{NO}_{2}{ }^{-} \rightarrow 2 \mathrm{NO}+\gamma-\mathrm{Fe}_{2} \mathrm{O}_{3}
\end{gathered}
$$

The reduction of the nitrite ions at the steel surface promotes the release of $\mathrm{O}^{2-}$. These $\mathrm{O}^{2-}$ ions oxidize the ferrous ion produced on the steel surface to form an insoluble and a stable barrier layer $\left(\gamma-\mathrm{Fe}_{2} \mathrm{O}_{3}\right)[22]$ over the steel surface.

Impedance spectra were obtained from a rotating disk electrode (specimen) in bicarbonate/chloride solutions with and without inhibitors. The spectra were fitted with an equivalent electrical circuit model as shown in Figure 2, and it showed good agreement with the experimental data (Figure $3 c, d$ ), where $R_{s}, R_{c t}, R_{a}, Q_{d l}$ and $Q_{a}$ represent the solution resistance, charge transfer resistance (metal/film interface), adsorption resistance (solution/film interface), double layer capacitance and passive film capacitance, respectively. The use of constant phase element (CPE) defined by the values of $n$ and $Q$, is commonly used to compensate for inhomogeneity of electrode surface. The impedance, $\mathrm{Z}$ of the constant phase element as given in [23]:

$$
\mathrm{Z}_{\mathrm{CPE}}=\mathrm{Q}^{-1}(\mathrm{j} \omega)^{-\mathrm{n}}
$$

where $\mathrm{Q}$ and $\mathrm{n}$ are constant and exponent, respectively, $\mathrm{j}=(\sqrt{-1})$ is an imaginary number, $\omega=2 \pi f$ is the angular frequency in rad/s calculated using $f$, the frequency in $\mathrm{H}_{z}$. At low frequencies, the impedance and phase angles describes the kinetic response for the charge transfer activity, while at high frequencies they depend on surface layer inhomogeneity [24].

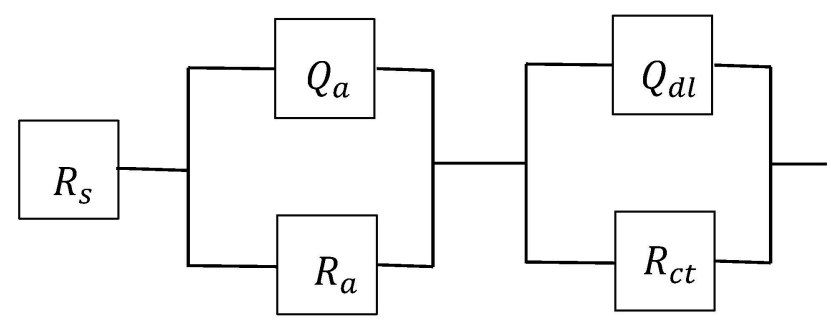

Figure 2. Equivalent circuit for impedance measurements.

Figure 3a,b represent the Nyquist and a combined Bode-phase angle plots in the presence and absence of nitrite at $2000 \mathrm{rpm}$. The addition of an inhibitor results in an increase in impedance, charge transfer resistance and a reduction of double layer capacitance as shown in Table 1. This implies that, the adsorption of the inhibitor at the metal/electrolyte interface enhances the formation of a stable oxide film and, consequently, results in a decrease in corrosion rate. The phase angle maxima increase with increasing nitrite concentration is either due to homogeneity of the absorbed inhibitor on the metal surface or to a reduction in porosity of the passive film [25]. The inhibitor efficiency was calculated according to Equation (18), and revealed the highest inhibition efficiency of $96.40 \%$ at $2 \mathrm{~g} / \mathrm{L}$. A further increase to $5 \mathrm{~g} / \mathrm{L}$ reduces inhibitor efficiency to $89.22 \%$ in agreement with the data obtained from the polarization curves. 


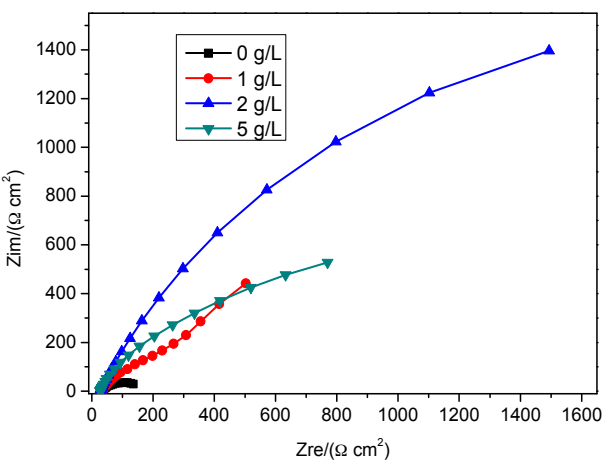

(a)

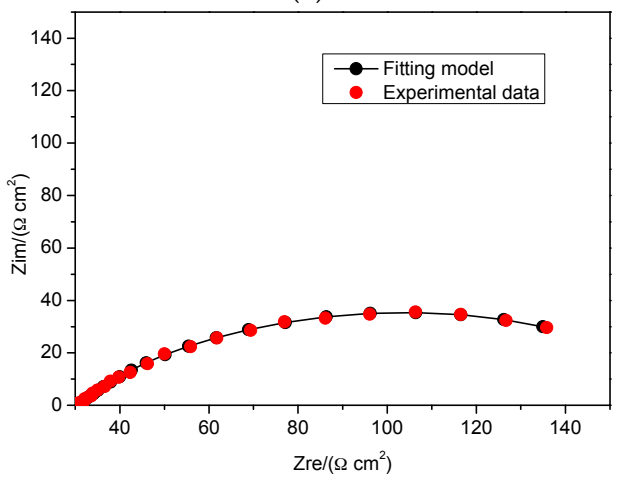

(c)

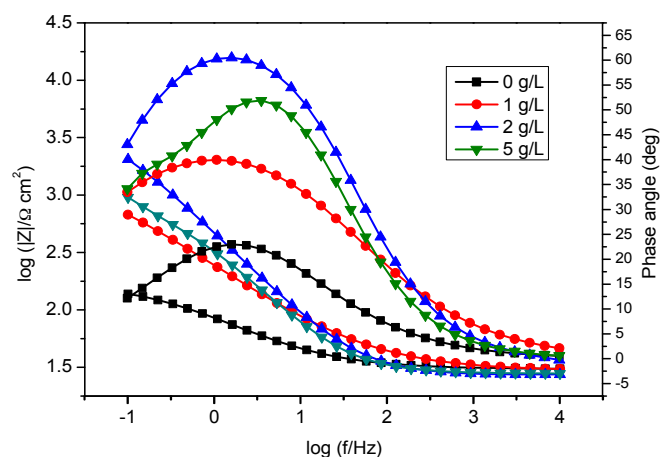

(b)

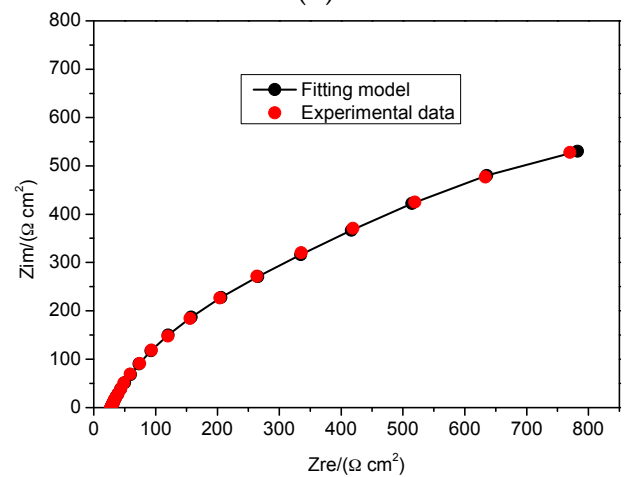

(d)

Figure 3. Impedance spectra for mild steel in bicarbonate chloride solution in the absence and presence of sodium nitrite at $2000 \mathrm{rpm}$ at room temperature: (a) Nyquist plots and (b) Bode and impedance magnitude vs. frequency plots; (c) Nyquist plots ( $0 \mathrm{~g} / \mathrm{L}$ nitrite) and (d) Nyquist plots ( $5 \mathrm{~g} / \mathrm{L}$ nitrite) for fitted and experimental data.

Table 1. Impedance parameters for mild steel in bicarbonate/chloride solution in the absence and presence of different concentration of sodium nitrite at $2000 \mathrm{rpm}$ at room temperature.

\begin{tabular}{ccccccccc}
\hline $\begin{array}{c}\text { Inh. Conc } \\
(\mathbf{g} / \mathbf{L})\end{array}$ & $\begin{array}{c}\mathbf{R}_{\mathbf{s}} \\
\left(\mathbf{\Omega} \cdot \mathbf{c m}^{\mathbf{2}}\right)\end{array}$ & $\begin{array}{c}\mathbf{R}_{\mathbf{c t}} \\
\left(\mathbf{\Omega} \cdot \mathbf{c m}^{2}\right)\end{array}$ & $\begin{array}{c}\mathbf{Q}_{\mathbf{d l}} \\
\left(\mathbf{F} \cdot \mathbf{c m}^{-2}\right)\end{array}$ & $\boldsymbol{n}$ & $\begin{array}{c}\mathbf{R}_{\mathbf{a}} \\
\left(\mathbf{\Omega} \cdot \mathbf{c m}^{\mathbf{2}}\right)\end{array}$ & $\mathbf{Q}_{\mathbf{a}}\left(\mathbf{F} \cdot \mathbf{c m}^{-\mathbf{2}}\right)$ & $\eta \mathbf{~ ( \% )}$ & $\begin{array}{c}\text { Surface } \\
\text { Coverage }(\theta)\end{array}$ \\
\hline 0 & 58.41 & 160.8 & $4.37 \times 10^{-3}$ & 0.59 & 29.96 & $1.26 \times 10^{-3}$ & 0 & 0 \\
$1 \mathrm{~g} \mathrm{NO}_{2}{ }^{-}$ & 18.54 & 2048 & $1.51 \times 10^{-3}$ & 0.55 & 10.68 & $5.0 \times 10^{-1}$ & 92.14 & 0.921 \\
$2 \mathrm{~g} \mathrm{NO}_{2}{ }^{-}$ & 15.33 & 4473 & $5.22 \times 10^{-4}$ & 0.76 & 11.06 & $1.02 \times 10^{-4}$ & 96.40 & 0.964 \\
$5 \mathrm{~g} \mathrm{NO}_{2}{ }^{-}$ & 27.80 & 1492 & $1.59 \times 10^{-3}$ & 0.78 & 303.5 & $9.4 \times 10^{-4}$ & 89.22 & 0.892 \\
\hline
\end{tabular}

\subsection{Effect of Potassium Iodide Additives}

The corrosion of steel in aqueous solution is known to be significantly exacerbated by hydroxyl ions, which form intermediate catalytic complexes on the steel surface [26]:

$$
\begin{gathered}
\mathrm{Fe}+\mathrm{OH}^{-} \rightleftharpoons(\mathrm{FeOH})_{\mathrm{ads}}+\mathrm{e} \\
(\mathrm{FeOH})_{\mathrm{ads}} \rightarrow \mathrm{FeOH}^{-}+\mathrm{e} \\
\mathrm{FeOH}^{+}+\mathrm{H}^{+} \rightleftharpoons \mathrm{Fe}^{2+}+\mathrm{H}_{2} \mathrm{O}(4 \mathrm{c})
\end{gathered}
$$

The replacement of the absorbed hydroxyl ions on the metal surface by halide ions can decrease the hydroxyl catalytic effect [27]:

$$
\begin{gathered}
\mathrm{Fe}+\mathrm{H}_{2} \mathrm{O}+\mathrm{Y}^{-} \rightleftharpoons(\mathrm{FeYOH})^{-} \text {ads }+\mathrm{H}^{+}+e \\
(\mathrm{FeYOH})^{-} \text {ads } \rightarrow \mathrm{FeYOH}+e
\end{gathered}
$$




$$
\mathrm{FeYOH}+\mathrm{H}^{+} \rightleftharpoons \mathrm{Fe}^{2+}+\mathrm{Y}^{-}+\mathrm{H}_{2} \mathrm{O}
$$

where $\mathrm{Y}$ represents a halide ion. This replacement ability follows the trend $\mathrm{I}^{-}>\mathrm{Br}^{-}>\mathrm{Cl}^{-}$. The greater effect of the iodide ion is attributed to its high hydrophobicity, low electronegativity and relatively large ionic radius [17], which enables $\mathrm{I}^{-}$ions to form a stronger bond with the iron surface.

Figure $4 \mathrm{a}-\mathrm{c}$ show the polarisation curves for corrosion of mild steel in the bicarbonate/chloride solutions with and without KI at the indicated concentration. The data shows that KI addition reduce both the rates of anodic Fe dissolution and cathodic hydrogen evolution. As reported by Heusler and Cartledge [28], the $\mathrm{I}^{-}$ion inhibits both the anodic and cathodic reactions, but predominantly affects the anodic site. The increase in corrosion potential $\left(E_{\text {corr }}\right)$ and decrease in corrosion rate with increasing KI concentration are similar to those reported previously $[17,29]$. The lowest passive current densities $\left(i_{p}\right)$ were obtained at $\mathrm{KI} / \mathrm{NO}_{2}{ }^{-}=1 / 1$ and $2 / 2$ as depicted in Figure $4 b$,c. Excessive quantities of KI increase the passivation current due to limited active site available for inhibitor adsorption [30]. Besides the replacement of the hydroxyl ions on the metal surface by halide ions, the chemisorption of $\mathrm{I}^{-}$ions can increase the hydrophobicity of the metal surface [31]:

$$
\begin{gathered}
\mathrm{FeIOH}+\mathrm{H}^{+} \rightleftharpoons \mathrm{Fe}^{2+}+\mathrm{I}^{-}+\mathrm{H}_{2} \mathrm{O} \\
\mathrm{Fe}^{2+}+\mathrm{I}^{-}+2 \mathrm{OH}^{-}+2 \mathrm{NO}_{2}^{-} \rightarrow 2 \mathrm{NO}+\gamma-\mathrm{Fe}_{2} \mathrm{O}_{3}+\mathrm{I}^{-}
\end{gathered}
$$

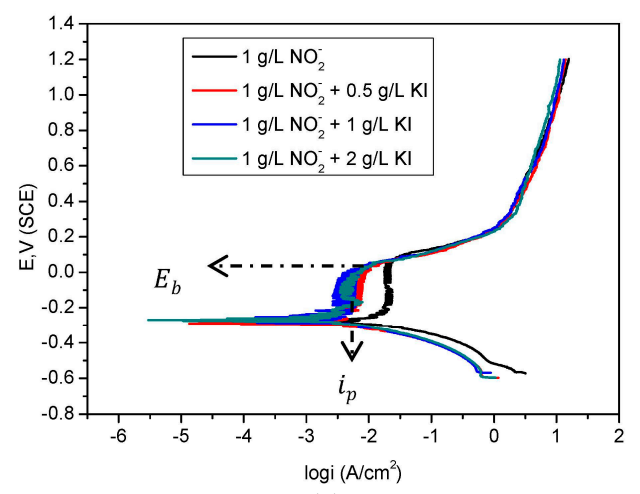

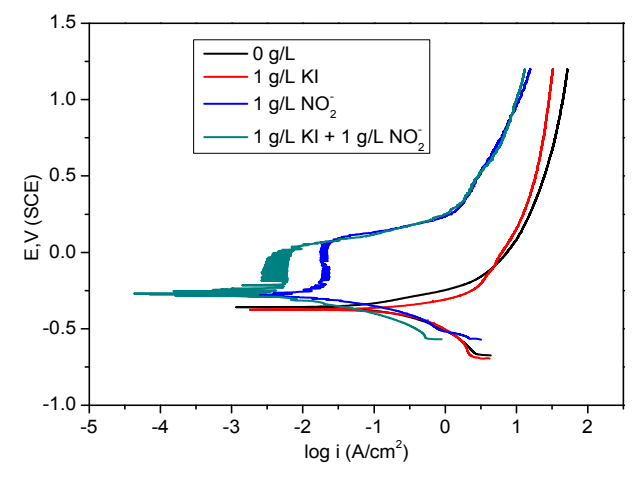

(b)

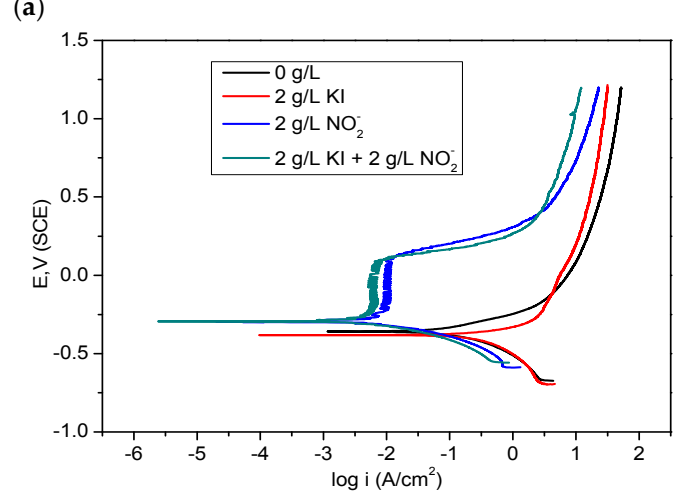

(c)

Figure 4. Polarization curves for mild steel in bicarbonate/chloride solution at $2000 \mathrm{rpm}$ at room temperature: (a) in absence and presence of different concentrations of $\mathrm{KI}(\mathbf{b}, \mathbf{c})$.

The iodide reacts with oxygen to form molecular iodine $\left(\mathrm{I}_{2}\right)$ [32] which reacts with the oxidized

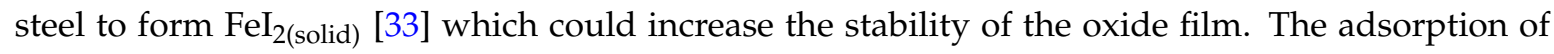
iodide molecules on the steel surface involves chemisorption $[34,35]$. The iodide ion slows down cathodic reaction, raising the hydrogen overpotential, whereas at the anode, its influence may act as a barrier to the hydroxyl ion, whose presence at the metal/solution interface is necessary for corrosion process [36]. 
The Nyquist and Bode Phase angle plots shown in Figure 5a-f, for bicarbonate/chloride solution in the absence and presence of different concentrations of KI additives, reveal that the addition of KI leads to a significant increase in the diameters of the semi-circles in the Nyquist plots and in the maxima phase angle in the Bode plots. The diameters and phase angle maxima increase with increasing concentrations of KI from 0.5 to $1 \mathrm{~g} / \mathrm{L}$, indicating that increasing KI concentration promotes inhibitor action. However, a further increase of KI concentration to $2 \mathrm{~g} / \mathrm{L}$ results in a decrease in both the diameter of the semi-circles in Nyquist plots and phase angle maxima, as shown in Figure 5a,b. These same trends are apparent in the charge transfer resistance given in Tables 2 and 3. The results suggest that more inhibitive passive films were achieved when the concentrations of both nitrites and KI are similar.

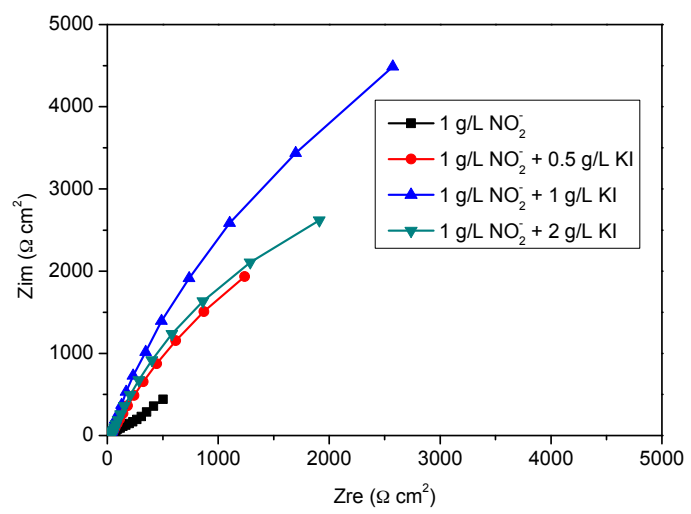

(a)

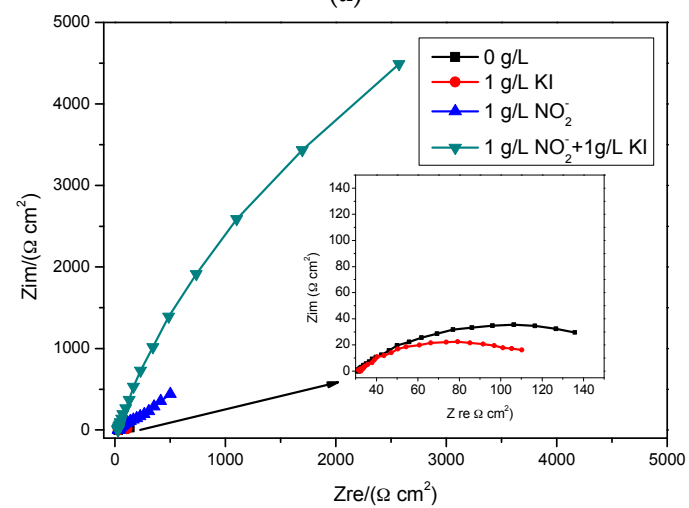

(c)

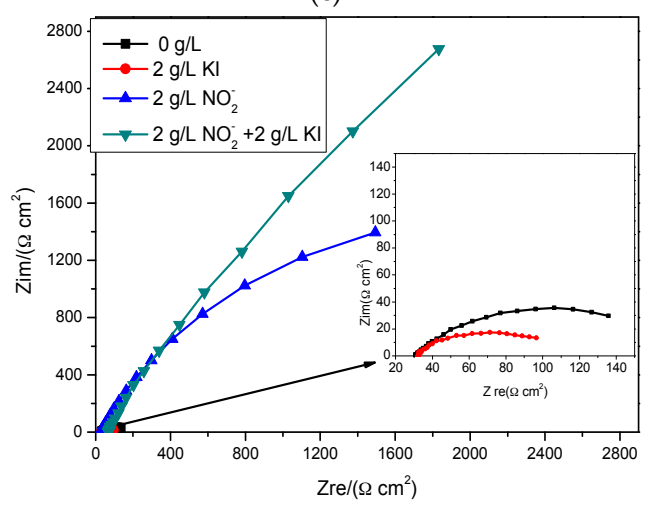

(e)

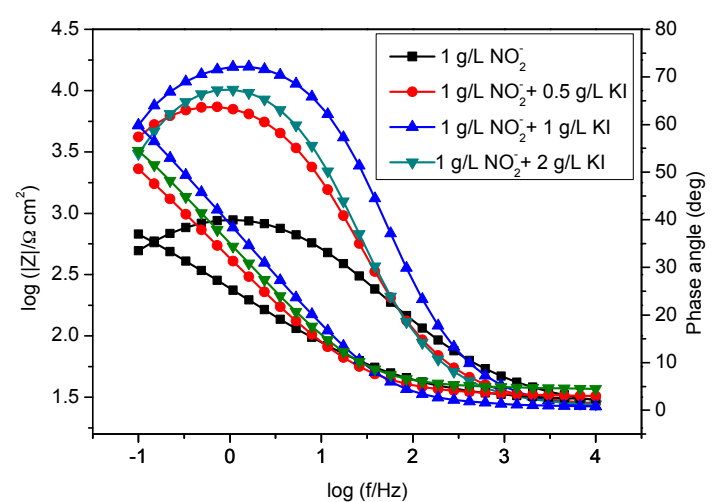

(b)

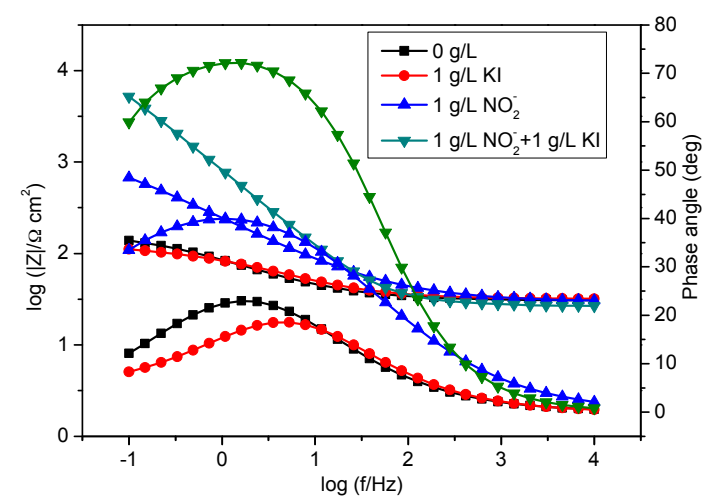

(d)

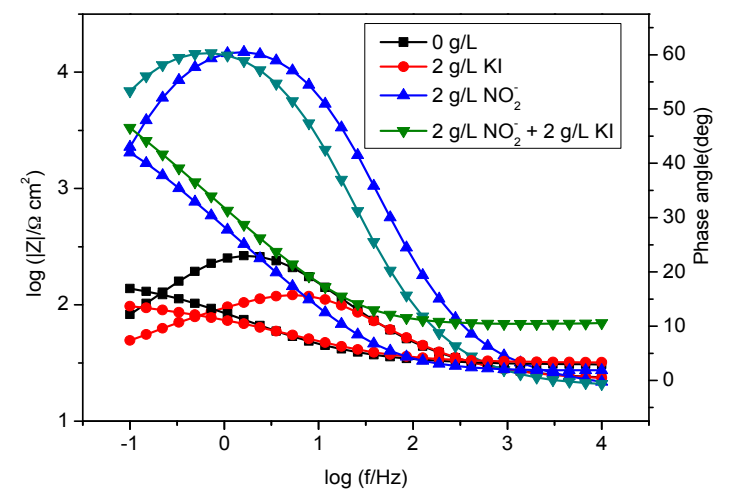

$(\mathbf{f})$

Figure 5. Impedance spectra for mild steel in bicarbonate/chloride solution at $2000 \mathrm{rpm}$ at room temperature: (a,b) Nyquist, Bode and impedance magnitude plots in absence and presence of $(\mathbf{c}, \mathbf{d})$ different concentrations of $\mathrm{KI}$ and $(\mathbf{e}, \mathbf{f})$ absence and presence of $\mathrm{KI}$. 
Table 2. Impedance parameters for mild steel in bicarbonate/chloride solution in the absence and presence of different concentrations of KI at $2000 \mathrm{rpm}$ at room temperature.

\begin{tabular}{|c|c|c|c|c|c|c|c|c|}
\hline $\begin{array}{l}\text { Inh. Conc } \\
\text { (g/L) }\end{array}$ & $\begin{array}{c}R_{s} \\
\left(\Omega \cdot \mathrm{cm}^{2}\right)\end{array}$ & $\begin{array}{c}R_{\mathrm{ct}} \\
\left(\Omega \cdot \mathrm{cm}^{2}\right)\end{array}$ & $\begin{array}{c}\mathrm{Q}_{\mathrm{dl}} \\
\left(\mathrm{F} \cdot \mathrm{cm}^{-2}\right)\end{array}$ & $\mathbf{n}$ & $\begin{array}{c}R_{a} \\
\left(\Omega \cdot \mathrm{cm}^{2}\right)\end{array}$ & $Q_{a}\left(F \cdot \mathrm{cm}^{-2}\right)$ & $\eta(\%)$ & $\begin{array}{c}\text { Surface } \\
\text { Coverage }(\theta)\end{array}$ \\
\hline 0 & 58.41 & 160.8 & $4.37 \times 10^{-3}$ & 0.59 & 29.96 & $1.26 \times 10^{-3}$ & 0 & 0 \\
\hline $1 \mathrm{KI}$ & 31.74 & 176.7 & $4.09 \times 10^{-2}$ & 0.22 & 65.92 & $2.60 \times 10^{-3}$ & 8.99 & 0.089 \\
\hline $1 \mathrm{NO}_{2}^{-}$ & 29.57 & 1911 & $1.49 \times 10^{-3}$ & 0.56 & 8.66 & $1.97 \times 10^{-5}$ & 91.58 & 0.916 \\
\hline $1 \mathrm{NO}_{2}+0.5 \mathrm{KI}$ & 22.50 & 10,621 & $5.70 \times 10^{-4}$ & 0.78 & 335.40 & $5.61 \times 10^{-3}$ & 98.48 & 0.985 \\
\hline $1 \mathrm{NO}_{2}+1 \mathrm{KI}$ & 26.94 & 12,009 & $3.76 \times 10^{-4}$ & 0.99 & 2156 & $5.31 \times 10^{-4}$ & 98.66 & 0.987 \\
\hline $1 \mathrm{NO}_{2}+2 \mathrm{KI}$ & 93.70 & 9029 & $3.85 \times 10^{-4}$ & 0.83 & 163.0 & $1.30 \times 10^{-3}$ & 98.21 & 0.982 \\
\hline
\end{tabular}

Table 3. Impedance parameters for mild steel in bicarbonate/chloride solution in the absence and presence of KI at $2000 \mathrm{rpm}$ at room temperature.

\begin{tabular}{|c|c|c|c|c|c|c|c|c|}
\hline $\begin{array}{l}\text { Inh. Conc } \\
(\mathrm{g} / \mathrm{L})\end{array}$ & $\begin{array}{c}R_{s} \\
\left(\Omega \cdot \mathrm{cm}^{2}\right)\end{array}$ & $\begin{array}{c}R_{\mathrm{ct}} \\
\left(\Omega \cdot \mathrm{cm}^{2}\right)\end{array}$ & $\begin{array}{c}Q_{\mathrm{dl}} \\
\left(\mathrm{F} \cdot \mathrm{cm}^{-2}\right)\end{array}$ & $\mathbf{n}$ & $\begin{array}{c}R_{a} \\
\left(\Omega \cdot \mathrm{cm}^{2}\right)\end{array}$ & $Q_{a}\left(F \cdot \mathrm{cm}^{-2}\right)$ & $\eta(\%)$ & $\begin{array}{c}\text { Surface } \\
\text { Coverage }(\theta)\end{array}$ \\
\hline 0 & 58.41 & 160.8 & $4.37 \times 10^{-3}$ & 0.59 & 29.96 & $1.26 \times 10^{-3}$ & 0 & 0 \\
\hline $2 \mathrm{KI}$ & 31.81 & 46.32 & $1.47 \times 10^{-2}$ & 0.59 & 33.97 & $3.30 \times 10^{-3}$ & -71.19 & -0.712 \\
\hline $2 \mathrm{NO}_{2}^{-}$ & 15.53 & 4473 & $5.22 \times 10^{-4}$ & 0.76 & 11.06 & $1.02 \times 10^{-4}$ & 96.40 & 0.964 oo \\
\hline $2 \mathrm{NO}_{2}+2 \mathrm{KI}$ & 22.30 & 13,347 & $3.78 \times 10^{-4}$ & 0.75 & 78.78 & $0.9 \times 10^{-4}$ & 98.79 & 0.988 \\
\hline
\end{tabular}

\subsection{Effect of Flow Velocity}

The synergistic effect of KI was studied under stagnant and various rotation speed conditions. The polarisation profile shows that passivation was achieved under flow conditions, whereas under stagnant conditions, two anodic peaks were apparent as illustrated in the polarisation profile shown in Figure 6. This implies that high electrode rotation speed facilitates film formation on the metal surface $[37,38]$. On the other hand, an unstable non-protective oxide film was formed under stagnant conditions, and as a result metal dissolution was uninhibited. It is apparent that the anodic current densities decrease while corrosion potentials become more noble [39] with increasing rotation speeds. $\mathrm{I}^{-}$promotes the replacement of hydroxyl ions, facilitating the adsorption of inhibitor to the metal surface:

$$
\mathrm{Inh}_{(\mathrm{sol})}+\mathrm{yH}_{2} \mathrm{O}_{(\mathrm{ads})} \rightleftharpoons \mathrm{Inh}_{(\mathrm{ads})}+\mathrm{yH}_{2} \mathrm{O}_{(\mathrm{sol})}
$$

The inhibitor combines with freshly formed $\mathrm{Fe}^{+}$ions on the steel surface, forming inhibitor metal complexes [40]:

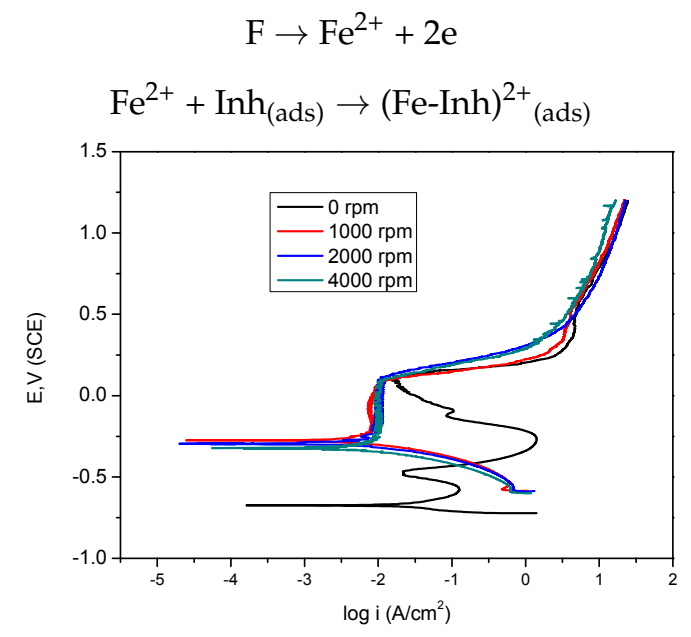

Figure 6. Polarization curves for mild steel in bicarbonate/chloride solution under stagnant conditions and different rotation speeds in the presence of $2 \mathrm{~g} / \mathrm{L} \mathrm{NO}_{2}{ }^{-}+2 \mathrm{~g} / \mathrm{L} \mathrm{KI}$ at room temperature. 
The resulting complexes can either inhibit or catalyse further metal dissolution, depending on their relative stability. Flow has both positive and negative influences on inhibitor efficiency; it increases mass transport of inhibitor molecules and oxygen to the steel surface, which can improve the inhibition performance. On the other hand, high velocity flow can increase mass transport of $\mathrm{Fe}^{2+}$ ions formed during metal dissolution away from the electrode surface to the bulk of solution. This impedes the formation of metal/inhibitor complexes on the electrode and further increase metal dissolution [41]. In our study, more (Fe-Inh) ${ }^{2+}$ complex was formed on the electrode under dynamic conditions as compared to stagnant conditions. The increased passivation was apparent in the polarization curves.

Impedance spectra are shown in Figure 7. The Nyquist plots (Figure 7a) show that the semi-circle increases with increasing rotation speed $(0-2000 \mathrm{rpm})$. This result implies that a more stable film forms as rotation speed increases. The passive films on the surface causes an increase in charge transfer resistance and a decrease in double layer capacitance [12]. However, at a higher rotation speed (4000 rpm), the charge transfer resistance decreases due to depletion of the (Fe-Inh) ${ }^{2+}$ complex, and the corrosion rate increases. The steel surface resistance increases with rotation speed as revealed in the Bode and impedance magnitude in Figure $7 \mathrm{~b}$ at low frequencies. The summaries of the EIS parameters are listed in Table 4 . The result is in agreement with the polarization data obtained.

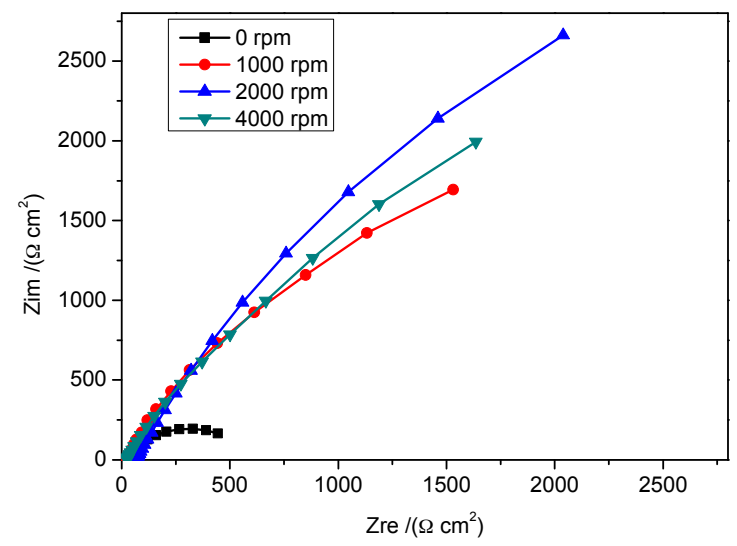

(a)

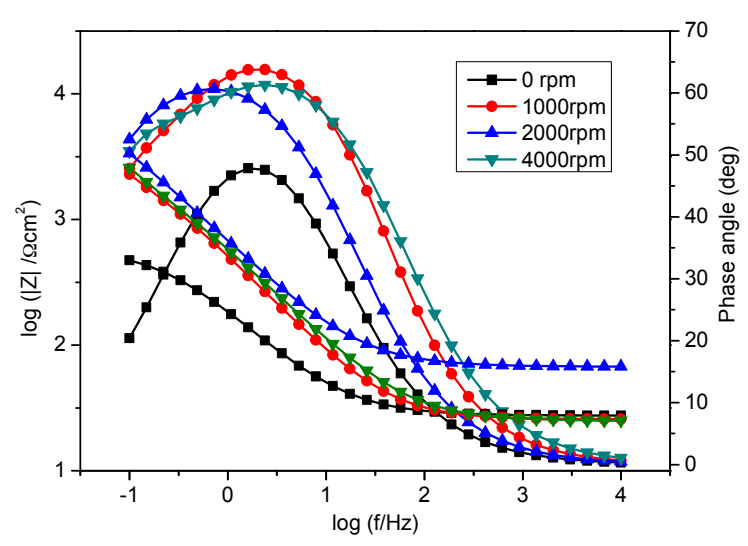

(b)

Figure 7. Impedance spectra for mild steel in bicarbonate chloride solution under stagnant and indicated rotating speeds in the presence of $2 \mathrm{~g} / \mathrm{L} \mathrm{NO}_{2}{ }^{-}+2 \mathrm{~g} / \mathrm{L} \mathrm{KI}$ at room temperature: (a) Nyquist plots and (b) Bode and impedance magnitude vs. frequency plots.

Table 4. Impedance parameters for mild steel in bicarbonate/chloride solution under stagnant conditions and different rotation speeds in the presence of $2 \mathrm{~g} / \mathrm{L} \mathrm{NO}_{2}{ }^{-}+2 \mathrm{~g} / \mathrm{L} \mathrm{KI}$ at room temperature.

\begin{tabular}{ccccccc}
\hline $\begin{array}{c}\text { Rotation } \\
\text { Speed (rpm) }\end{array}$ & $\mathbf{R}_{\mathbf{s}}\left(\boldsymbol{\Omega} \cdot \mathbf{c m}^{\mathbf{2}}\right)$ & $\mathbf{R}_{\mathbf{c t}}\left(\boldsymbol{\Omega} \cdot \mathbf{c m}^{\mathbf{2}}\right)$ & $\begin{array}{c}\mathbf{Q}_{\mathbf{d l}} \\
\mathbf{( F \cdot \mathbf { c m } ^ { - 2 } )}\end{array}$ & $\mathbf{n}$ & $\mathbf{R}_{\mathbf{a}}\left(\boldsymbol{\Omega} \cdot \mathbf{c m}^{\mathbf{2}}\right)$ & $\mathbf{Q}_{\mathbf{a}}\left(\mathbf{F} \cdot \mathbf{c m}^{-\mathbf{2}}\right)$ \\
\hline 0 & 27.45 & 508.3 & $1.26 \times 10^{-3}$ & 0.76 & 61.01 & $1.79 \times 10^{-4}$ \\
1000 & 25.61 & 3597 & $1.14 \times 10^{-3}$ & 1 & 1536 & $5.60 \times 10^{-4}$ \\
2000 & 22.3 & 13,347 & $3.78 \times 10^{-4}$ & 0.75 & 78.79 & $0.92 \times 10^{-4}$ \\
4000 & 24.87 & 3859 & $3.4 \times 10^{-4}$ & 1 & 3771 & $3.92 \times 10^{-4}$ \\
\hline
\end{tabular}

\subsection{SEM and EDS Analysis}

The surface morphology of the test specimens in the presence and absence of KI additives was investigated using scanning electron microscopy as shown in Figure 8 and the elemental composition of the corrosion product was analysed using EDS. Figure 8a shows the surface morphology before corrosion testing. It is obvious that specimens immersed in solution without nitrite or KI additives shows significant surface deterioration, and pitting corrosion is evident in the surface morphology (Figure $8 \mathrm{~b}$ ). The addition of $1 \mathrm{~g} / \mathrm{L}$ of nitrite to the solution decreases the corrosion, but a few cracks 
have formed on the corrosion product on the steel surface (Figure 8c). In presence of combined $\mathrm{NO}_{2}{ }^{-}$ with $\mathrm{KI}(0.5,1$, and $2 \mathrm{~g} / \mathrm{L})$, the steel specimens exhibit less corrosion damage and retain, relatively smooth surfaces (Figure $8 \mathrm{c}-\mathrm{e}$ ). This indicates that the adsorption of $\mathrm{I}^{-}$ions on mild steel expedites the formation of more stable films. The oxide film is presumably more adhered to the steel surface in the presence of $\mathrm{I}^{-}$ions, and as a result impedes iron dissolution. However, a few cracks are observed when KI concentration was increased to $2 \mathrm{~g} / \mathrm{L}$. Figure 9 shows the cross-sectional SEM images of corrosion products (Figure 9a,c,e) and their corresponding EDS spectra (Figure 9b,d,f) taken after the corrosion tests. The presence of inhibitor influences the corrosion product morphologies. The addition of KI improves the compactness and the stability of the corrosion product on the steel surface as shown in Figure 9c. This implies that the diffusion of $\mathrm{Fe}^{2+}$ from the steel and the ingress of corrosive ions to the steel surface were inhibited.

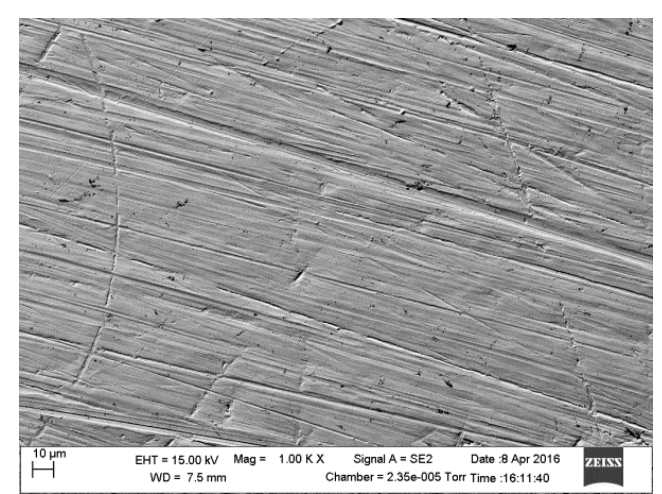

(a)

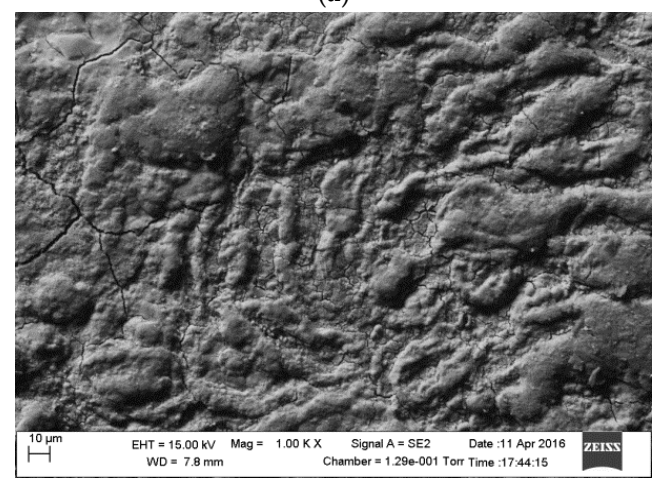

(c)

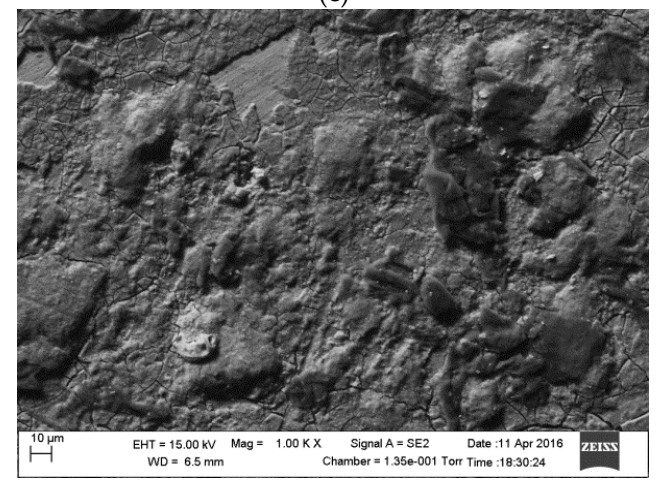

(e)

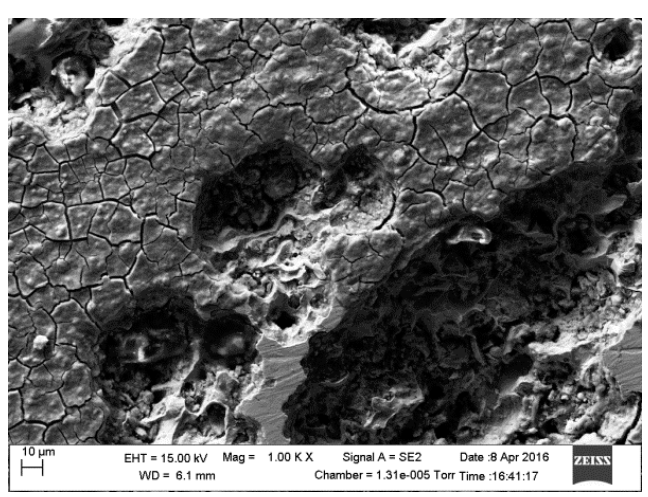

(b)

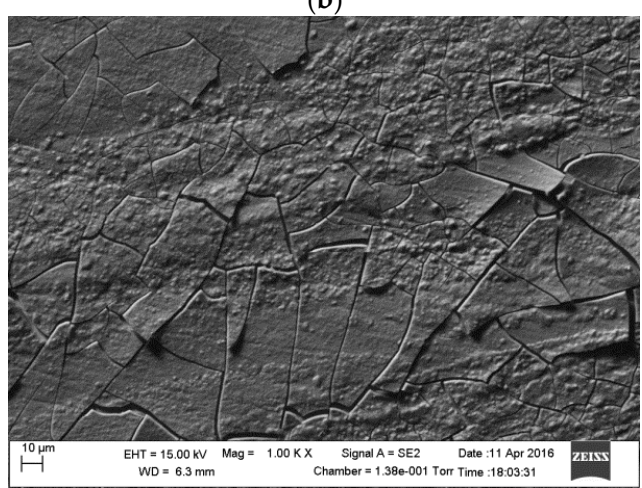

(d)

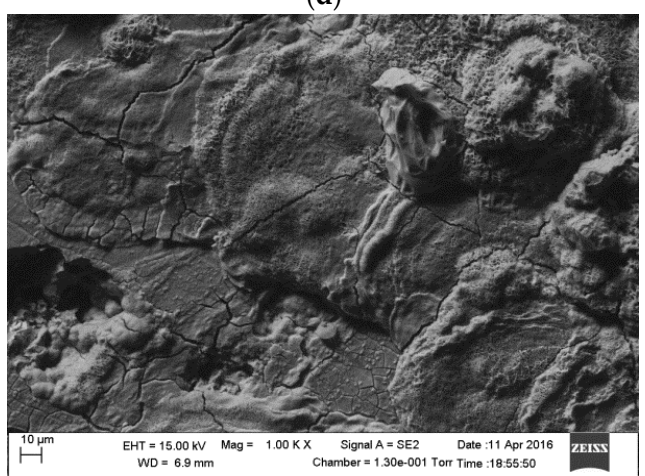

(f)

Figure 8. Scanning electron micrographs of mild steel surface before and after corrosion testing: (a) before immersion; (b) without inhibitor; (c) $1 \mathrm{~g} / \mathrm{L} \mathrm{NO}_{2}{ }^{-}$; (d) $1 \mathrm{~g} / \mathrm{L} \mathrm{NO}_{2}{ }^{-}+0.5 \mathrm{~g} / \mathrm{L} \mathrm{KI}$; (e) $1 \mathrm{~g} / \mathrm{L} \mathrm{NO}_{2}{ }^{-}+1 \mathrm{~g} / \mathrm{L} \mathrm{KI}$; (f) $1 \mathrm{~g} / \mathrm{L} \mathrm{NO}_{2}{ }^{-}+2 \mathrm{~g} / \mathrm{L} \mathrm{KI}$. 


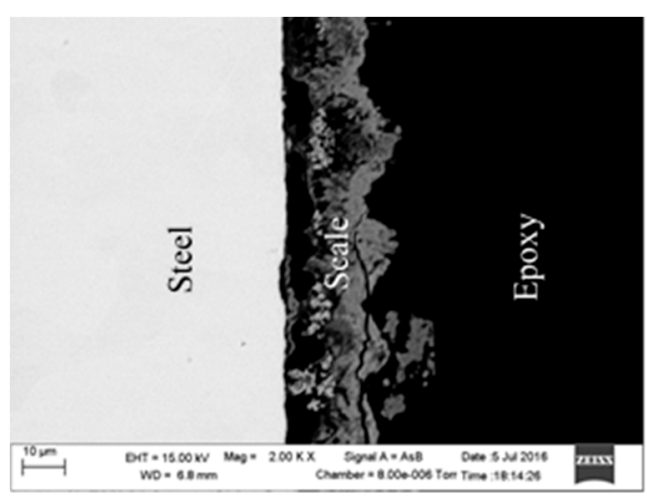

(a)

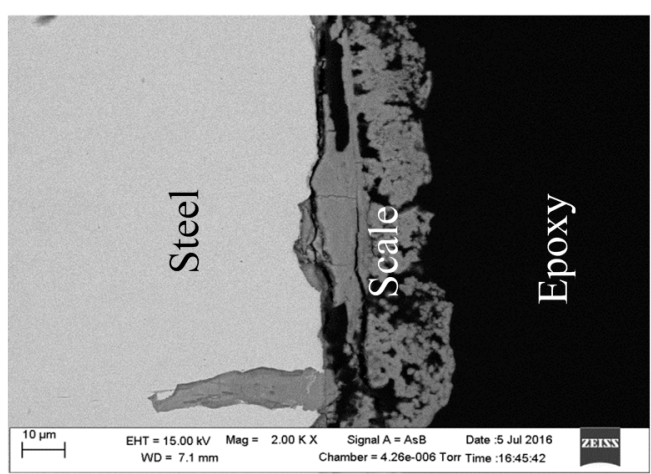

(c)

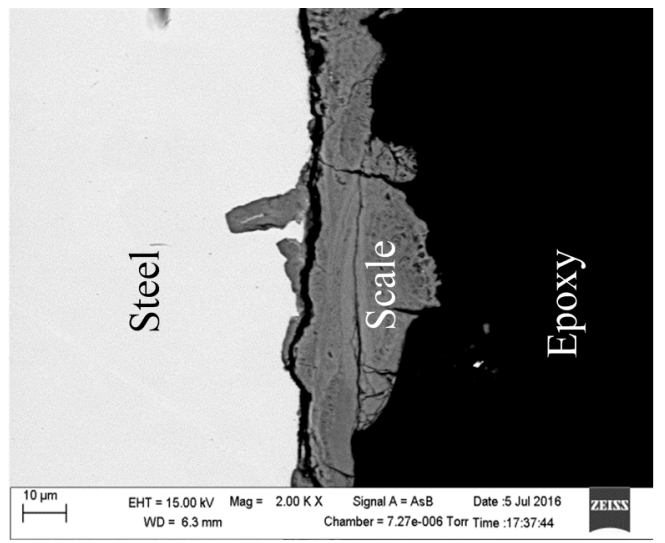

(e)

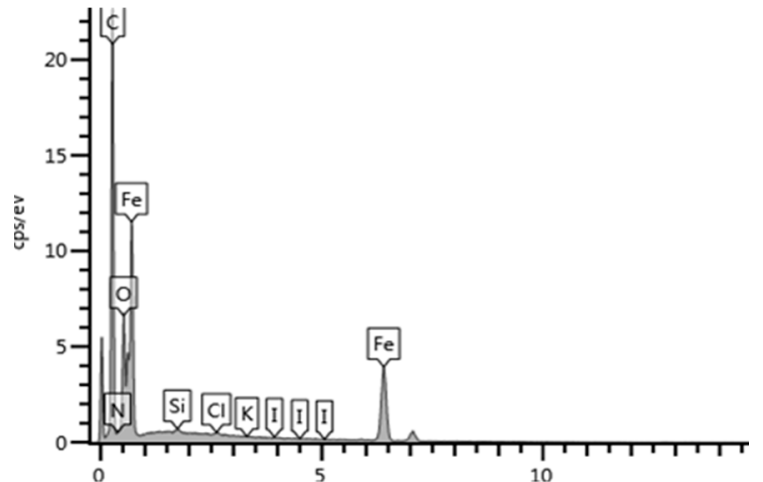

(b)

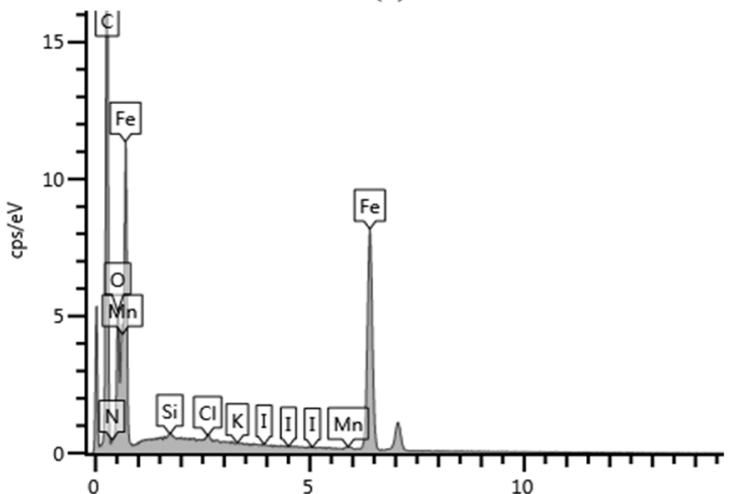

(d)

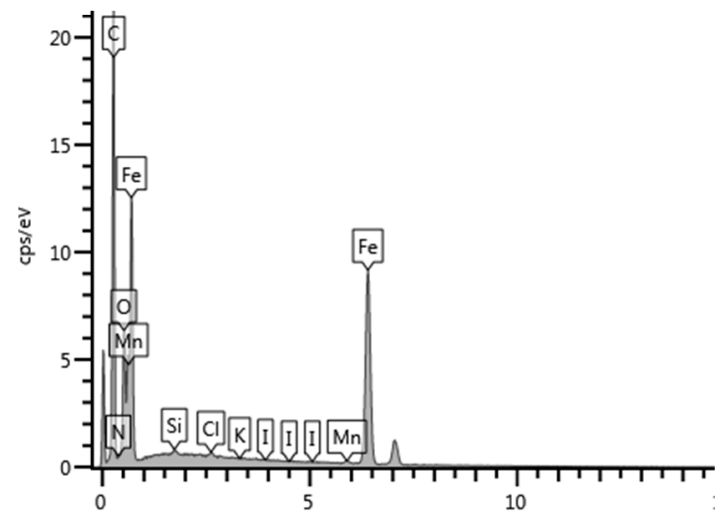

(f)

Figure 9. SEM cross-sectional images and EDS spectra after corrosion tests: (a,b) un-inhibited $(\mathbf{c}, \mathbf{d})$ nitrites $(\mathbf{e}, \mathbf{f})$ nitrites + KI containing solutions.

\subsection{XRD Analysis}

XRD patterns in Figure $10 \mathrm{~b}-\mathrm{d}$, show the different diffraction peaks associated with surfaces tested in solutions without inhibitor, with $1 \mathrm{~g} \mathrm{NO}_{2}^{-}$and $1 \mathrm{~g} / \mathrm{L} \mathrm{NO}_{2}{ }^{-}+1 \mathrm{~g} / \mathrm{L} \mathrm{Kl}$, respectively. The figures show similar peak patterns, $\alpha-\mathrm{FeO}(\mathrm{OH})$ (goethite) and $\gamma-\mathrm{Fe}_{2} \mathrm{O}_{3}$ (maghemite) were the iron oxyhydroxides present in the corrosion products. Goethite peak was not present in the uninhibited specimen as shown in Figure 10b. The formation of goethite is mainly attributed to the oxidation of $\gamma-\mathrm{Fe}_{3} \mathrm{O}_{4}$ by atmospheric $\mathrm{O}_{2}$ after removal from the test solutions. Figure 10a shows the pattern of the specimen before corrosion test. 


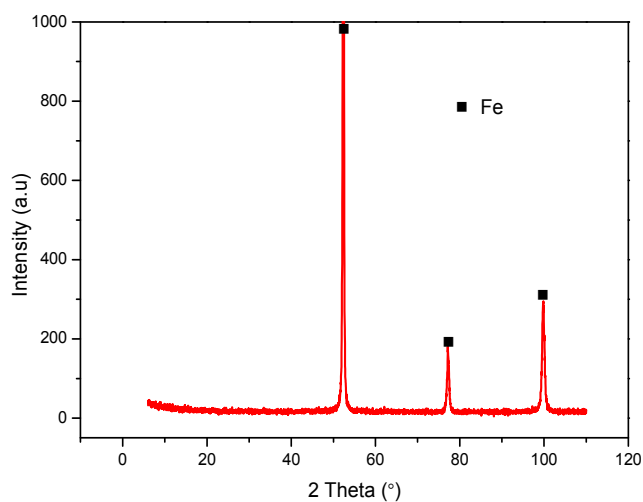

(a)

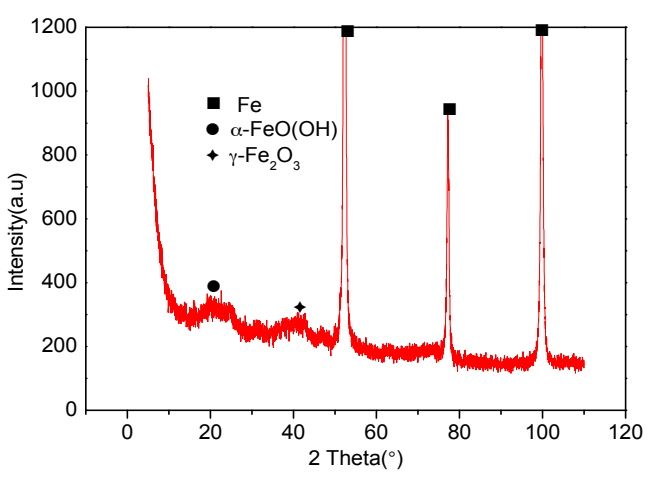

(c)

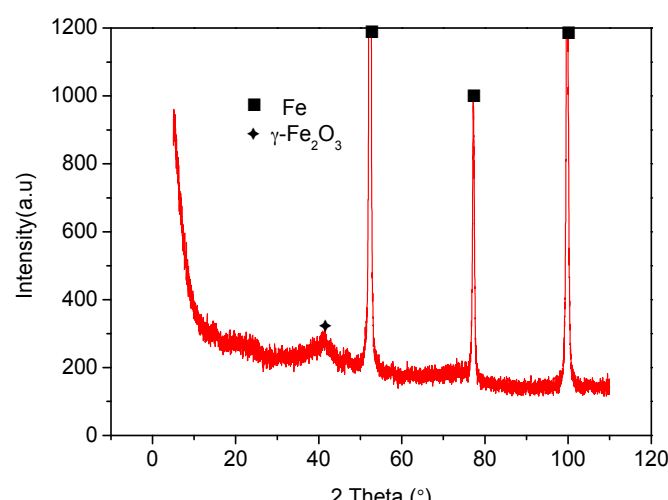

(b)

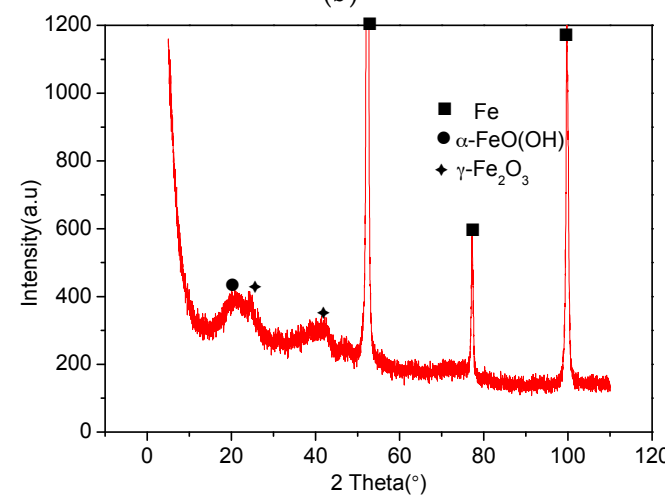

(d)

Figure 10. XRD analysis of corrosion product after corrosion test of mild steel in bicarbonate/chloride solution at $2000 \mathrm{rpm}$ : (a) un-immersed (b) un-inhibited (c) $1 \mathrm{~g} / \mathrm{L} \mathrm{NO}_{2}^{-}$(d) $1 \mathrm{~g} / \mathrm{L} \mathrm{NO}_{2}^{-}+1 \mathrm{~g} / \mathrm{L} \mathrm{KI}$.

\section{Experimental}

\subsection{Materials and Solutions}

Cylindrical carbon steel rod (Ø16 mm) of grade AISI 1020 was used as the rotating disc electrode (RDE). The chemical composition of the as-received rod was analysed using a Field Emission Electron Probe Microanalyzer (JXA-8530 F) (JEOL, Peabody, MA, USA) as shown in Table 5. The test samples were polished using emery papers of grit sizes ranging from 220 to 800, rinsed with acetone and dried with air. The sample preparation procedures for all specimens were completed within 8 min prior to the subsequent electrochemical tests, to ensure an identical surface oxide film for all specimens. The solution was prepared by dissolving analytical grade sodium bicarbonate $(5 \mathrm{~g})$ and $2 \mathrm{~g}$ of sodium chloride in $1 \mathrm{~L}$ of distilled deionized water which corresponds to $0.06 \mathrm{M}$ and $0.03 \mathrm{M}$ bicarbonate and chloride concentrations, respectively. All experiments were conducted in solution containing different concentrations of nitrite $(0-5 \mathrm{~g} / \mathrm{L})$ and potassium iodide $(0-2 \mathrm{~g} / \mathrm{L})$ to study the influence of sodium nitrite and potassium iodide, respectively. The electrochemical tests were performed at ambient temperature $\left(22 \pm 3^{\circ} \mathrm{C}\right)$ at $\mathrm{pH}(8.2 \pm 0.1)$.

Table 5. Chemical composition of mild steel (wt \%).

\begin{tabular}{ccccccc}
\hline $\mathbf{C}$ & $\mathbf{S i}$ & $\mathbf{M n}$ & $\mathbf{C r}$ & $\mathbf{C u}$ & $\mathbf{N i}$ & $\mathbf{F e}$ \\
\hline 0.20 & 0.32 & 0.79 & 0.01 & 0.01 & 0.01 & Bal 98.7 \\
\hline
\end{tabular}

\subsection{Electrochemical Test}

The corrosion tests were carried out in a $1 \mathrm{~L}$ glass cell containing the test solution $(400 \mathrm{~mL})$ and a rotating disk electrode (working electrode) fitted into rotating shaft of an analytical rotator AFASRE 
747 (Pine Instrument Company, Grove, PA, USA). The unexposed surface area was embedded in epoxy, leaving exposed area of $2.01 \mathrm{~cm}^{2}$ in contact with the corrosive solution. The reference electrode was a saturated calomel electrode (SCE) connected to the cell by a Lugging capillary, and platinum was used as counter electrode. The angular speed $(\omega)$ of the rotating disk electrode was controlled by the ASR RDE speed controller. The minimum and maximum rotation speed of the RDE performed in the tests was 1000 and $4000 \mathrm{rev} / \mathrm{min}$, respectively. Corrosion evaluation was monitored by potentiodynamic polarization and electrochemical impedance spectroscopy. Before electrochemical tests, the working electrode was immersed in test solution at open circuit potential (OCP) for $30 \mathrm{~min}$ to attain a stable state. Electrochemical impedance spectroscopy (EIS) measurements were conducted at open-circuit. The measuring frequencies ranged from $10 \mathrm{kHz}$ to $0.1 \mathrm{~Hz}$ with a perturbing alternating current (AC) amplitude of $10 \mathrm{mV}$ and a sampling rate of 10 points per decade. Polarization studies were performed after EIS tests at room temperature at a scan rate of $0.5 \mathrm{mV} / \mathrm{s}$ relative to the open circuit corrosion potential using a Bio-Logic instrument Model VSP 0508 potentiostat (BioLogic, Knoxville, TN, USA). The potentiodynamic polarisation was obtained from a starting potential of $-0.30 \mathrm{~V}$ vs. SCE to a final potential of $+1.20 \mathrm{~V}$ vs. SCE. The results obtained from EIS were analysed and fitted to equivalent circuits using Z Fit contained in the EC-Lab ${ }^{\circledR}$ [23]. Data obtained from EIS were used to calculate the inhibition efficiency $(\eta)$ as [42]:

$$
\eta(\%)=\frac{R_{c t(i n h)}-R_{c t}}{R_{c t(i n h)}} \times 100
$$

where $R_{c t(i n h)}$ and $R_{c t}$ are charge transfer resistance in the presence and absence of inhibitors, respectively. The degree of surface coverage $(\theta)$ was calculated using the relationship:

$$
\theta=\eta(\%) / 100(10)
$$

\subsection{Scanning Electron Microscopy (SEM)}

Scanning electron microscopy (SEM) imaging were performed before and after corrosion tests using a Zeiss Sigma VP Field Emission Scanning Electron Microscope (Oxford XMax 50 with silicon drift energy dispersive spectroscopy (EDS) detector (Jena, Germany)), in secondary electron (SE) imaging mode with an accelerating beam voltage of $15 \mathrm{kV}$. For cross-section analyses, specimens were cut and mounted with epoxy resin. The surface was polished with alumina $0.05 \mu \mathrm{m}$ without etching and fine carbon films were sputtered on the specimens to reduce charging of the epoxy resin.

\subsection{X-ray Diffraction}

The corrosion products were characterized using a PANalytical X' Pert PRO MPD powder X-ray Diffractometer (Almelo, The Netherlands), $40 \mathrm{keV}, 40 \mathrm{~mA},\left(\mathrm{Co} \mathrm{K}_{\alpha}\right)$ with the multi-purpose vertical stage and a $5 \mathrm{~mm}$ mask in Bragg-Brentano geometry. Data were collected from $2 \theta$ values of $5^{\circ}-110^{\circ}$ at a step size of $0.0084^{\circ}$.

\section{Conclusions}

This study examined the corrosion inhibition of sodium nitrite and the synergistic effect of potassium iodide on the corrosion behaviour of mild steel in high concentration bicarbonate chloride solution. Sodium nitrite functions as an anodic inhibitor, and the inhibition efficiency was significantly improved by the addition of $\mathrm{I}^{-}$. The data suggest a mixed-inhibition mechanism, with a dominant effect on the anodic reaction, based on the formation of a passivating oxide $\left(\gamma-\mathrm{Fe}_{2} \mathrm{O}_{3}\right)$ that decreases the rate of metal dissolution, is responsible for the effective inhibition. Corrosion inhibition efficiency was optimum at $\mathrm{NO}_{2}{ }^{-} / \mathrm{KI}=$ unity. The synergistic effect of $\mathrm{KI}$ was due to the displacement of hydroxyl ions and the presence of nitrite in the solution, which facilitates the oxidation of iron in the divalent state $\left(\mathrm{Fe}_{3} \mathrm{O}_{4}\right)$ to form a stable tenacious trivalent oxide $\left(\gamma-\mathrm{Fe}_{2} \mathrm{O}_{3}\right)$ on the steel/solution interface. Inhibition efficiency increased with rotation speeds $(0-2000 \mathrm{rpm})$ due to rapid oxide film formation. However, a further increase of rotation speed $(4000 \mathrm{rpm})$, expedites the removal of $\left(\mathrm{Fe}^{2+}-\mathrm{Inh}\right)_{(\mathrm{ads})}$ from the 
steel surface and accelerates metal dissolution. These results suggest that sodium nitrite inhibitor can be made more environmentally friendly and effective when synergised with potassium iodide, since smaller amounts of nitrite are required when used in conjunction with KI, which is a non-toxic compound to both human and animals.

Acknowledgments: The authors would like to thank the Australian Government and Queensland University of Technology for providing the financial assistance for this work. Some characterizations were performed at the Central Analytical Research Facility (CARF) operated by the Institute for Future Environments (QUT).

Author Contributions: Geoffrey Will and Willem Dekkers are the supervisory team, and both helped in designing the experiment. Jennifer MacLeod analysed the SEM data, and Gaius Debi Eyu performed the experiments and the data analyses.

Conflicts of Interest: The authors declare no conflict of interest.

\section{References}

1. Han, J.; Zhang, J.; Carey, J.W. Effect of bicarbonate on corrosion of carbon steel in $\mathrm{CO}_{2}$ saturated brines. Int. J. Greenh. Gas Control 2011, 5, 1680-1683. [CrossRef]

2. Alves, V.A.; Brett, C. The influence of alloying on the passive behaviour of steels in a bicarbonate medium studied by electrochemistry and XPS. Key Eng. Mater. Trans. Tech. Publ. 2002, 230, 436-439. [CrossRef]

3. Castro, E.; Vilche, J.; Arvia, A. Iron dissolution and passivation in $\mathrm{K}_{2} \mathrm{CO}_{3} / \mathrm{KHCO}_{3}$ solutions. rotating ring disc electrode and XPS studies. Corros. Sci. 1991, 32, 37-50. [CrossRef]

4. Davies, D.; Burstein, G. The effects of bicarbonate on the corrosion and passivation of iron. Corrosion 1980, 36, 416-422. [CrossRef]

5. Linter, B.; Burstein, G. Reactions of pipeline steels in carbon dioxide solutions. Corros. Sci. 1999, 41, 117-139. [CrossRef]

6. El-Etre, A.; Abdallah, M. Natural honey as corrosion inhibitor for metals and alloys. II. C-steel in high saline water. Corros. Sci. 2000, 42, 731-738. [CrossRef]

7. Galliano, F.; Landolt, D. Evaluation of corrosion protection properties of additives for waterborne epoxy coatings on steel. Prog. Org. Coat. 2002, 44, 217-225. [CrossRef]

8. Kim, J.-G.; Kim, Y.-W. Cathodic protection criteria of thermally insulated pipeline buried in soil. Corros. Sci. 2001, 43, 2011-2021. [CrossRef]

9. Lin, B.-L.; Lu, J.-T.; Kong, G. Synergistic corrosion protection for galvanized steel by phosphating and sodium silicate post-sealing. Surf. Coat. Technol. 2008, 202, 1831-1838. [CrossRef]

10. Ali, M.; Mustafa, C.; Habib, M. Effect of molybdate, nitrite and zinc ions on the corrosion inhibition of mild steel in aqueous chloride media containing cupric ions. J. Sci. Res. 2008, 1, 82-91. [CrossRef]

11. Wachter, A. Sodium Nitrite as Corrosion Inhibitor for Water. Ind. Eng. Chem. 1945, 37, 749-751. [CrossRef]

12. Ashassi-Sorkhabi, H.; Asghari, E. Effect of hydrodynamic conditions on the inhibition performance of 1-methionine as a "green" inhibitor. Electrochim. Acta 2008, 54, 162-167. [CrossRef]

13. Beecher, J.; Dinkel, C.; Corwin, S. Corrosion inhibition with sodium nitrite. J. (Am. Water Works Assoc.) 1959, $51,1175-1180$.

14. Lee, D.Y.; Kim, W.C.; Kim, J.G. Effect of nitrite concentration on the corrosion behaviour of carbon steel pipelines in synthetic tap water. Corros. Sci. 2012, 64, 105-114. [CrossRef]

15. Raman, R.S.; Siew, W. Role of nitrite addition in chloride stress corrosion cracking of a super duplex stainless steel. Corros. Sci. 2010, 52, 113-117. [CrossRef]

16. Sanad, S.; Ismail, A.; Mahmoud, N. Inhibition effect of potassium iodide on corrosion of stainless steel in hydrochloric acid solution. J. Mater. Sci. 1992, 27, 5706-5712. [CrossRef]

17. Oguzie, E.E.; Li, Y.; Wang, F.H. Corrosion inhibition and adsorption behavior of methionine on mild steel in sulfuric acid and synergistic effect of iodide ion. J. Colloid Interface Sci. 2007, 310, 90-98. [CrossRef] [PubMed]

18. Pavithra, M.K.; Venkatesha, T.V.; Vathsala, K.; Nayana, K.O. Synergistic effect of halide ions on improving corrosion inhibition behaviour of benzisothiozole-3-piperizine hydrochloride on mild steel in $0.5 \mathrm{M} \mathrm{H} 2 \mathrm{SO} 4$ medium. Corros. Sci. 2010, 52, 3811-3819. [CrossRef]

19. Eliyan, F; Alfantazi, A. Sensitivity of the passive films on API-X100 steel heat-affected zones (HAZs) towards trace chloride concentrations in bicarbonate solutions at high temperature. Mater. Corros. 2014, 65, 1111-1119. [CrossRef] 
20. Eliyan, F.F.; Mahdi, E.-S.; Alfantazi, A. Electrochemical evaluation of the corrosion behaviour of API-X100 pipeline steel in aerated bicarbonate solutions. Corros. Sci. 2012, 58, 181-191. [CrossRef]

21. Jones, D. Corrosion of central heating systems. Eng. Fail. Anal. 1997, 4, 179-194. [CrossRef]

22. Bloom, M.; Goldenberg, L. $\gamma-\mathrm{Fe}_{2} \mathrm{O}_{3}$ and the passivity of iron. Corros. Sci. 1965, 5, 623-630. [CrossRef]

23. Popova, A.; Sokolova, E.; Raicheva, S.; Christov, M. AC and DC study of the temperature effect on mild steel corrosion in acid media in the presence of benzimidazole derivatives. Corros. Sci. 2003, 45, 33-58. [CrossRef]

24. Khaled, K.; Hackerman, N. Investigation of the inhibitive effect of ortho-substituted anilines on corrosion of iron in $1 \mathrm{M} \mathrm{HCl}$ solutions. Electrochim. Acta 2003, 48, 2715-2723. [CrossRef]

25. Moretti, G.; Guidi, F.; Grion, G. Tryptamine as a green iron corrosion inhibitor in $0.5 \mathrm{M}$ deaerated sulphuric acid. Corros. Sci. 2004, 46, 387-403. [CrossRef]

26. Bockris, J.M.; Drazic, D.; Despic, A. The electrode kinetics of the deposition and dissolution of iron. Electrochim. Acta 1961, 4, 325-361. [CrossRef]

27. Bala, H. The corrosion of iron in sulphate solutions at $\mathrm{pH}=0-2$. Electrochim. Acta 1984, 29, 119-129. [CrossRef]

28. Heusler, K.; Cartledge, G. The influence of iodide ions and carbon monoxide on the anodic dissolution of active iron. J. Electrochem. Soc. 1961, 108, 732-740. [CrossRef]

29. Mu, G.; Li, X. Inhibition of cold rolled steel corrosion by Tween-20 in sulfuric acid: Weight loss, electrochemical and AFM approaches. J. Colloid Interface Sci. 2005, 289, 184-192. [CrossRef] [PubMed]

30. Harek, Y.; Larabi, L. Corrosion inhibition of mild steel in $1 \mathrm{~mol} \mathrm{dm}-3 \mathrm{HCl}$ by oxalic $N$-phenylhydrazide- $N^{\prime}$-phenylthiosemicarbazide. Kem. Ind. 2004, 53, 55-61.

31. Kuznetsov, Y.I.; Andreev, N. Reviews on Corrosion Inhibitors Science and Technology; NACE International: Houston, TX, USA, 1996.

32. Mor, E.; Scotto, V.; Wrubl, C. Hexamethylenetetramine Hydroiodide (HMTA-I) as a Corrosion Inhibitor for Steel in HCI Pickling Solutions. Br. Corros. J. 1972, 7, 276-280. [CrossRef]

33. Hoinkis, E. Review of the Adsorption of Iodine on Metal and Its Behavior in Loops; Oak Ridge National Laboratory: Oak Ridge, TN, USA, 1970.

34. Attar, T.; Harek, Y. Inhibition effect of potassium iodide on the corrosion of carbon steel (XC 38) in acidic medium. Int. J. Adv. Chem. 2014, 2, 139-142. [CrossRef]

35. Khadom, A.A.; Yaro, A.S. Protection of low carbon steel in phosphoric acid by potassium iodide. Prot. Met. Phys. Chem. Surf. 2011, 47, 662-669. [CrossRef]

36. Cavallaro, L.; Felloni, L.; Trabanelli, G.; Pulidori, F. The anodic dissolution of iron and the behaviour of some corrosion inhibitors investigated by the potentiodynamic method. Electrochim. Acta 1964, 9, 485-494. [CrossRef]

37. Abdallah, M. Corrosion behaviour of 304 stainless steel in sulphuric acid solutions and its inhibition by some substituted pyrazolones. Mater. Chem. Phys. 2003, 82, 786-792. [CrossRef]

38. Bommersbach, P.; Alemany-Dumont, C.; Millet, J.-P.; Normand, B. Hydrodynamic effect on the behaviour of a corrosion inhibitor film: Characterization by electrochemical impedance spectroscopy. Electrochim. Acta 2006, 51, 4011-4018. [CrossRef]

39. Eyu, G.D.; Will, G.; Dekkers, W.; MacLeod, J. Effect of hydrodynamics and surface roughness on the electrochemical behaviour of carbon steel in CSG produced water. Appl. Surf. Sci. 2015, 357, 506-515. [CrossRef]

40. Branzoi, V.; Branzoi, F.; Baibarac, M. The inhibition of the corrosion of Armco iron in $\mathrm{HCl}$ solutions in the presence of surfactants of the type of N-alkyl quaternary ammonium salts. Mater. Chem. Phys. 2000, 65, 288-297. [CrossRef]

41. Jiang, X.; Zheng, Y.; Ke, W. Effect of flow velocity and entrained sand on inhibition performances of two inhibitors for $\mathrm{CO}_{2}$ corrosion of $\mathrm{N} 80$ steel in 3\% NaCl solution. Corros. Sci. 2005, 47, 2636-2658. [CrossRef]

42. Valcarce, M.; Vázquez, M. Phosphate ions used as green inhibitor against copper corrosion in tap water. Corros. Sci. 2010, 52, 1413-1420. [CrossRef]

(C) 2016 by the authors; licensee MDPI, Basel, Switzerland. This article is an open access article distributed under the terms and conditions of the Creative Commons Attribution (CC-BY) license (http://creativecommons.org/licenses/by/4.0/). 